\title{
The Society for Libyan Studies Archive: History, Organisation, Recent and Future Developments
}

\author{
Victoria Leitch, ${ }^{1}$ David Mattingly, ${ }^{2}$ Niccolò Mugnai ${ }^{3}$
}

\section{Abstract}

This paper presents an update on the development of the Society for Libyan Studies archive. We begin with a brief reminder about the history of the archive and its current location, moving on to explain the challenging cataloguing process and future plans for digitisation, of both the catalogue and the physical contents of the archive. We also look at the potential of the archive for researchers and outline a few projects that recently benefited from its reorganisation.

\section{History of the Archive}

This paper presents an update on the organisation and development of the Society for Libyan Studies archive and the note published in Libyan Studies 46 (Leitch and Nikolaus 2015). The SLS archive was established in 1988 at the University of Newcastle thanks to the donation of the papers of David Smith and Olwen Brogan and John Dore's efforts to secure it a first institutional home. In 2012 the archive was moved to the University of Leicester, where there is a larger community of postgraduate students and academics following research on Libyan and broader North African subjects. The archive is currently housed in a suite of rooms at 6 University Road, Leicester, with specially built shelving and plan chests for the storage of large maps and plans.

\section{Figure 1. The Society for Libyan Studies archive at 6 University Road, Leicester.}

The move exposed not only the desperate need to reorganise and improve cataloguing of the material, but also its conservation and preservation needs. The archive mainly contains documents (correspondence, notebooks, research materials, SLS paperwork), photographs, drawings, maps and plans, ceramic material and smaller amounts of other finds. Many of the major collections relate to deceased scholars, such as Dame Kathleen Kenyon, John Ward-Perkins, Lady Olwen Brogan, Barri Jones, Charles Daniels, John Dore, and Martyn Webb. Others have donated paperwork and materials during their own lifetime, such as John Riley and Philip Kenrick. There are plans to incorporate archives from David Mattingly's Libyan projects as publications are completed.

\section{Figure 2. Documents related to the Libya Exploration Society foundation in 1969.}

As well as being a primary record of the Society's work (and extending also to projects of key actors prior to the foundation of the Society), the archive has huge research potential. The archive includes some unpublished material, but also large

\footnotetext{
${ }^{1}$ Society for Libyan Studies, Publications Manager.

${ }^{2}$ School of Archaeology and Ancient History, University of Leicester.

${ }^{3}$ British School at Rome.
} 
data sets from previous fieldwork missions that are ripe for further analysis and reinterpretation, since new tools now exist for digitisation, spatial mapping and scientific analysis that were not available when the excavations were originally carried out. New research agendas looking at sedentarisation, state formation, social behaviour, use of space, networks and so on can now be followed. Threats to Libya's heritage have accelerated and magnified since 2011 and the archive contains crucial data that can assist with site conservation and reconstruction. The restrictions on travel to and fieldwork in Libya mean that now is the right moment to reorganise, digitise and study these resources. In particular, the digitisation of as much material as possible will be invaluable, not only for UK researchers, but more significantly, for Libyan heritage professional, academics, students and interested lay-people, who can share in access to the material.

The archive has a primary focus on the geographical area of modern-day Libya, but also includes materials relating to other parts of North Africa, especially where these were included in the broader collection of papers donated by or on behalf of individuals. The subjects covered are archaeology, history, geography, the natural sciences and linguistics.

\section{The Cataloguing}

Initial work on the archive documentation at Newcastle was carried out by Linda Green with John Dore, with further collation when the material was moved to Leicester in the summer of 2012 by Tyr Fothergill, who also did some emergency conservation of fragile documents, glass plates, and some objects.

From October 2012 to July 2017 Niccolò Mugnai held the position of the Society's John Dore Scholar, with responsibilities for the organisation, access, and day-to-day management of the archive. Part of his work was dedicated to further cataloguing of the materials, with particular regard to the newly acquired collections. In February 2013 the Society for Libyan Studies was donated the 'Martin and Audrey Webb Cyrenaica Archive', consisting of maps and aerial/ground photographs of Cyrene and its hinterland, and in June 2014 the 'James Thorn Archive' was moved from Canterbury to Leicester. Suitable storage had to be found for these materials and access numbers were added to the catalogue. In 2014 the 'Charles Daniels Archive', collecting photographs and notes of this scholar's extraordinary work in Fazzan in the 1950s and 1960s, was also added to the existing SLS collections.

While all the initial cataloguing work was important, it became increasingly apparent, because of the way material had been accrued, that there were many inconsistencies built into the numbering scheme. Much of the original packaging up of materials had been unsystematic, so materials that ought to relate to the same cataloguing heading were in fact distributed across multiple boxes of mixed materials. An important decision was thus made by the Society for Libyan Studies in 2015 to completely re-do the catalogue to a consistent standard and with necessary reorganisation of the storage of these materials. After discussions with the University of Leicester librarian, Caroline Sampson, the decision was taken to employ a professional archivist and to utilise the same cataloguing software system as used for other archives in the 
University's Special Collections. This is a system called CALM, supplied by Axiell, and fully compatible with best-practice professional archiving standards (General International Standard Archival Description or ISAD(G)). CALM's functionality, specifically the creation of authority terms and indexing, was seen as advantageous in creating additional access points for the collection.

Inevitably, initial estimates of the time required to catalogue the c. 250 boxes of papers and materials were somewhat optimistic, in part because of the time taken to reorganise the materials and, in this process, the identification of a need to carry out a great deal of careful conservation work and repackaging as the cataloguing progressed. A succession of archivists was thus employed between October 2015 and December 2017 (with some gaps between post-holders) to carry out the work. The first archivist appointed was Leanne Harrington (October 2015 - June 2016) and she was responsible for establishing the archive record structure within CALM. The highest level recognised specific collections (fonds) related to individuals - these largely linked to the person who had donated materials, or on whose behalf this had been done. Leanne Harrington catalogued 120 boxes, relating to Peter Addyman; D.M. Bailey; Charles Daniels; John Dore; Richard Goodchild; Cedric N. Johns; G.D.B. Jones; Philip Kenrick; Kathleen Kenyon; Dorothy Marshall; Mervyn Popham; John Riley; Roland C. Shaw; David J. Smith; John B. Ward-Perkins; Martyn Webb and David Whitehouse.

The basic record structure is as follows:

\section{Reference Number}

Title

Scope and Content

Date

Extent and Medium

Creator

Location (Site or Area)

Level

Previous Reference Number(s)

Notes

Generally, below the fond level, material is arranged by site or area and then divided according to the following formats: Correspondence, Notes (sub-divided into those connected with publications and general notes), Publications, Sketches/Drawings, Photographs, Negatives, Glass Slides, Slides (that is, cardboard or plastic-mounted), Maps, Plans, Press Cuttings, Miscellaneous and Finds.

Subsequently, Sarah Wood (August-December 2016) completed work on the Thorn archive (c.40 boxes) and some other minor collections, while Jane Sellek (JuneDecember 2017) primarily worked on the voluminous Olwen Brogan archive (65 boxes). Most of the SLS archives have now been fully catalogued in the CALM software system, following a consistent hierarchical arrangement. A finding aid has been generated from the catalogue to facilitate the location of specific items within the archive. 
The bulk of the archive has thus now been archived professionally using the CALM software under licence through the University of Leicester, but additional material has continued to arrive since the last phase of that work in 2017 and there are additional project materials held in Leicester that could be added. A further phase of cataloguing is thus envisaged in the near future.Thanks to the assistance of Vicky Holmes, Caroline Sampson's successor as University Archivist, the catalogue is now available via the University of Leicester online archive collections within CALM (follow http://www.societyforlibyanstudies.org/resources/archive/). The data have also been extracted from the catalogue and, with the assistance of Charlotte Roueche, Will Wootton and King's Digital Laboratory, transformed into a searchable online database format. This is now available online at https://www.slsgazetteer.org/cat search/.

\section{Donating to or Accessing the Archive}

The John Dore Scholar has also been involved in monitoring access to the archive. In a busy research environment, such as that of the past and ongoing archaeological projects at Leicester, the daily use (and movement) of archival collections needed to be carefully controlled to prevent loss or misplacement of materials. Archaeologists as we all know - are very good at unearthing things from the ground but often need to be supervised in the organisation of their work spaces! The John Dore Scholar has also facilitated other researchers' work in the archive, including doctoral students, post-doctoral fellows and scholars from UK and international institutions. Indeed, one of the primary aims of the Society for Libyan Studies is to encourage use of its archive, especially in a period when undertaking field research in Libya and elsewhere in North Africa is proving very difficult. The use of archival resources for the development of local archaeology and for cultural heritage protection across these regions is now becoming a fundamental component of many international projects (see, for instance, Mugnai et al. 2017; Menozzi et al. 2018; Sharfeddin 2018).

After the SLS archive was moved to Leicester, its collections have been accessed for study purposes by a number of scholars, including Susan Walker, Corisande Fenwick, Philip Kenrick, Graeme Barker, Michel Bonifay, Loïc Mazou, Claudio Capelli, Eleonora Gasparini, Cecilia Buccellato, and the late Sebastiano Tusa among many others. The archive has also been largely used by a number of recent $\mathrm{PhD}$ students working on ancient Libya (Ahmed Emrage, Mohamed Hesein, Mohamed Omar, Ahmed Buzaian, Andrea Zocchi), as well as by post-doctoral researchers (Julia Nikolaus, Louise Rayne, Martin Sterry). After the departure of Niccolò Mugnai from Leicester, the John Dore Scholarship was awarded to Ahmed Buzaian in 2017-19, who continued the activities of his predecessor with the same dedication and enthusiasm.

Offers of donations to the archive are always welcome, though the Society will make careful evaluation of the material before acceptance and donors are requested to assign copyright in the materials to the Society. Those wishing to donate material or desiring to consult the physical archive should, in the first instance, contact the General Secretary of the Society on gensec@societyforlibyanstudies.org, who will pass all requests to the responsible individuals at Leicester. 


\section{Archive-Based Research Projects}

Since its arrival in Leicester, a number of important research projects have been undertaken using material in the archive. A few of them are outlined here to demonstrate the significant potential of this resource and the need to continue to preserve and digitise its contents, to open it up far beyond the walls of the archive.

\section{The Fazzan Project (David Mattingly)}

Extensive use was made of the detailed records of Charles Daniels by the Fazzan project in order to complete publication of his work on this remote desert area of Libya and the 'lost civilisation' of the Garamantes. Thanks to funding from the Leverhulme Trust, the British Academy, the Society for Libyan Studies, and the Universities of Leicester and Newcastle, the study of the Daniels' archive collections went alongside renewed fieldwork in Fazzan from 1997 to 2002. The significant results of this archival and field research are now published in a dedicated, fourvolume series (Mattingly 2003; 2007; 2010; 2013).

\section{Libyan Antiquities at Risk (Susan Walker, David Mattingly, Niccolò Mugnai, Julia Nikolaus)}

The project 'Libyan Antiquities at Risk' (LAaR), funded by the Society for Libyan Studies and the AHRC Cultural Engagement Fund, was carried out at the University of Leicester in 2015-17 with the aim to create a digital reference collection of Libyan sculptural antiquities that are endangered by destruction and looting (Mugnai et al. 2017). The project made large use of the photographic collections held in the SLS archive, which were added to an online database (accessible at https://laar.le.ac.uk/). In addition to the creation of this digital resource, the project has fostered collaboration and exchange of information among a wide range of stakeholders: UK and international academics, cultural heritage operators (ICOM, UNESCO, the Art Loss Register), museum curators, police officers, and professional antiquities dealers. The work undertaken for LAaR has complemented the activities of the 'Endangered Archaeology in the Middle East and North Africa Project' (EAMENA) (see in particular Rayne et al. 2017; Nikolaus et al. 2018).

The Trans-Sahara Project (David Mattingly, Aurélie Cuénod, Chloë Duckworth, Victoria Leitch)

The Trans-Sahara project carried out analysis of materials from the Daniels' excavations to investigate the themes of trade and mobile technologies within the frame of this large ERC-funded project. In particular, Cuénod looked at the compositional signatures of copper alloys in Fazzan, establishing that some of these were certainly of Mediterranean origin and revealing clear evidence of Garamantian reworking of these metals (Duckworth et al. 2015; Leitch et al. 2017). Similarly, Duckworth's analysis of vessel glass, glass beads and bangles demonstrated that as well as importing material from the Mediterranean, the Garamantes were actively recycling some of this glass and making their own beads (Duckworth et al. 2015; $2016 \mathrm{a} / \mathrm{b})$. Leitch's detailed work on pottery fabrics has shed light on both handmade and imported Roman productions (Leitch et al. 2016; 2017; 2018).

\section{The Future: Digital Enhancements}


The archive is growing as we speak, and material from the excavations in Fazzan and at the site of Euesperides will be added over the coming years as their publications are completed. In addition, we have had several recent donations of photographs from the middle of the twentieth century, documenting the colonial history of Libya and adding to the Society's tradition of publishing research on modern history in addition to its traditional field of archaeology. An important recent donation was a complete run of the Sunday Ghibli newspaper in a series of bound volumes. We intend also to advance further with the digitisation of some key elements of the archive, notably the photographic collections, if we can secure the necessary funds. This will importantly enable North African scholars to access their cultural heritage online.

\section{References}

Duckworth, C.N. Cuenod, A. and Mattingly, D.J. 2015. Non-destructive $\mu$ XRF analysis of glass and metal objects from sites in the Libyan pre-desert and Fazzan. Libyan Studies 46: 14-34.

Duckworth, C.N., Mattingly, D.J. and Smith, V. 2016a. From the Mediterranean to the Libyan Sahara. Chemical analyses of Garamantian glass. Journal of Archaeological Science: Reports 7: 633-39.

Duckworth, C.N., Mattingly, D.J., Chenery, S. and Smith, V.C. 2016b. End of the line? Glass bangles, technology, recycling, and trade in Islamic North Africa. Journal of Glass Studies 58: 135-69.

Leitch, V. and Nikolaus, J. 2015. The Society for Libyan Studies Archive: past, present and future. Libyan Studies 46: 151-56.

Leitch, V., Mattingly, D.J., Williams, M., Norry, M., Wilkinson, I., Stocker, C. and Farman, T. 2010. Provenance of clays in Garamantian ceramics from Jarma, Fazzan region, (south-west Libya): a combined geochemical and microfossil analysis. Journal of Archaeological Science: Reports 10: 114.

Leitch, V., Bonifay, M., Capelli, C. and Mattingly, D.J. 2018. Pre-desert Tripolitania: a new archaeological and archaeometrical examination of Red Slip Ware from the Ghirza excavations and the Libyan Valleys Survey. Rei Cretariae Romanae Fautorum Acta 45: 759-63.

Leitch, V., Duckworth, C., Cuénod, A., Mattingly, D.J., Sterry, M and Cole, F. 2017. Early Saharan trade: the inorganic evidence. In D.J. Mattingly, V. Leitch, C.N. Duckworth, A. Cuenod, M. Sterry, and F. Cole (eds), Trade in the Ancient Sahara and Beyond. Cambridge: Cambridge University Press, 287-340.

Menozzi, O., Di Valerio, E., Tordone, V. and Mancini, M.C. 2018. L'archivio dell'Università di Chieti tra documentazione analogica e digitalizzazione. Quaderni di Archeologia della Libya 21: 307-12.

Mattingly, D.J. (ed.) 2003. The Archaeology of Fazzan, Volume 1, Synthesis. Society for Libyan Studies, Department of Antiquities, London

Mattingly, D.J. (ed.) 2007. The Archaeology of Fazzan. Volume 2, Site Gazetteer, Pottery and other Survey Finds. Society for Libyan Studies, Department of Antiquities, London.

Mattingly, D.J. (ed.) 2010. The Archaeology of Fazzan. Volume 3, Excavations Carried out by C.M. Daniels. London: Society for Libyan Studies, Department of Antiquities, London.

Mattingly, D.J. (ed.) 2013. The Archaeology of Fazzan, Volume 4. Survey and Excavations at Old Jarma (Ancient Garama) Carried out by C. M. Daniels (1962-69) and the Fazzan Project (19972001). Society for Libyan Studies, Department of Antiquities, London.

Mugnai, N., Nikolaus, J., Mattingly, D.J. and Walker, S. 2017. Libyan Antiquities at Risk: protecting portable cultural heritage. Libyan Studies 48: 11-21.

Nikolaus, J., Mugnai, N., Rayne, L., Zerbini, A., Mattingly, D.J., Walker, S., Abdrbba, M., Alhaddad, M., Buzaian, A. and Emrage, A. 2018. Training, partnerships, and new methodologies for protecting Libya's cultural heritage. Quaderni di Archeologia della Libya 21: 351-58.

Rayne, L., Sheldrick, N. and Nikolaus, J. 2017. Endangered archaeology in Libya: recording damage and destruction. Libyan Studies 48: 23-49.

Sharfeddin, F. 2018. Towards a new Central DoA Archive. The project for an archive management system for the maps and drawings archive at the Red Castle (Tripoli). Quaderni di Archeologia della Libya 21: 289-91. 